\title{
Buffalo (Bubalus bubilis) colostrum and milk fat globule membrane fractions are potent antioxidants
}

\author{
N. Brijesha, H. S. Aparna* \\ Department of Studies in Biotechnology, University of Mysore, Manasagangotri, Mysore-570 006, Karnataka, India.
}

\begin{tabular}{|c|c|}
\hline ARTICLE INFO & ABSTRACT \\
\hline $\begin{array}{l}\text { Article history: } \\
\text { Received on: } 24 / 12 / 2016 \\
\text { Accepted on: } 27 / 01 / 2017 \\
\text { Available online: } 20 / 03 / 2017\end{array}$ & $\begin{array}{l}\text { Colostrum is the first liquid food for the new born baby, secreted after the parturition. After few days of } \\
\text { maturation the colostrum turns to milk. The cream or fat fraction of milk consists of fat droplets composed } \\
\text { primarily of triacylglycerols that are secreted from the apical surface of the mammary cells surrounded by } \\
\text { cellular thin membranes membrane, the fat globule membrane (FGM), formed by proteins which have been }\end{array}$ \\
\hline $\begin{array}{l}\text { Key words: } \\
\text { Antioxidants, Bubalus bubilis, } \\
\text { colostrum, fat globule membrane, } \\
\text { milk, reducing power. }\end{array}$ & $\begin{array}{l}\text { suggested to be cholesterolemia-lowering factors, inhibitors of cancer cell growth, vitamin binders, } \\
\text { antioxidant, bactericidal, suppressors of multiple sclerosis. FGM was isolated from buffalo colostrum and } \\
\text { milk, the fat content was }>2 \text {-fold higher in the former than in the latter. The colostrum fat globule membrane } \\
\text { (CFGM) fraction also showed significantly higher protein content than milk fat globule membrane (MFGM) } \\
\text { extract. Further, the SDS-PAGE separation of the total proteins from the CFGM and MFGM showed } \\
\text { differential banding pattern. Antioxidative property of the two FGM extracts was deliberated based on their } \\
\text { free radical scavenging ability and reducing power. CFGM was found to exhibit a relatively higher } \\
\text { antioxidant and reductive capacity than the MFGM fractions. The results obtained in the present study } \\
\text { showcases the superior beneficial health effects of the CFGM over the MFGM. }\end{array}$ \\
\hline
\end{tabular}

\section{INTRODUCTION}

Milk is a complex biological fluid used as a food by all the mammalians in nature and also in the manufacture of a wide range of dairy products. Cows are the largest milk providing animal in the world. Milk from other animal species such as buffalo, ewes, goat and camel are essential to the human diet in various parts of the world. Globally, buffalo milk represents the second largest quantity of milk produced, with more than 97 million tons/year [1]. Buffalo milk is also one of the compositionally richest milks [2]. Compared to other animals fat constitutes the main fraction of buffalo milk, with almost twice the fat content of bovine milk $(7.4-8.8 \%(\mathrm{w} / \mathrm{w})$ vs $3.6-4.7 \%$ $(w / w))[3,4]$ and this fat is responsible for the high energetic and nutritive value of buffalo milk. Colostrum, the lacteal secretion vital for mammalian newborn is a complex physiological fluid loaded with free oligosaccharides, glycoproteins, gangliosides, phagocytes, antimicrobial and immune-enhancing components

\footnotetext{
* Corresponding Author

Aparna H.S., Department of Studies in Biotechnology, University of

Mysore, Manasagangotri, Mysore-570 006, Karnataka, India

E-mail: hsa.uom @gmail.com
}

which are unique compared to normal milk $[5,6]$. The core of the milk fat globule (MFG) is mainly composed of triacylglycerols (TAG); esters of fatty acids and glycerol constitute total $98 \%$ of milk lipids. MFGs originate near the basal region of the alveolar lumen of secretory cells as small droplets of fat. They migrate through the cytoplasm, gradually increasing in size, as the synthesis of TAG proceeds. MFG are secreted from the apical surface of the cell, surrounded by a thin biological bilayer membrane called the Milk Fat Globule Membrane (MFGM) [7, 8]. Milk is a complex biological fluid used as a food by all the mammalians in nature and also in the manufacture of a wide range of dairy products. Cows are the largest milk providing animal in the world. Milk from other animal species such as buffalo, ewes, goat and camel are essential to the human diet in various parts of the world. Globally, buffalo milk represents the second largest quantity of milk produced, with more than 97 million tons/year [1]. Buffalo milk is also one of the compositionally richest milks [2]. Compared to other animals fat constitutes the main fraction of buffalo milk, with almost twice the fat content of bovine milk $(7.4-8.8 \%(\mathrm{w} / \mathrm{w})$ vs $3.6-4.7 \%(\mathrm{w} / \mathrm{w})) \quad[3,4]$ and this fat is responsible for the high energetic and nutritive value of buffalo milk. Colostrum, the lacteal secretion vital for mammalian newborn is a complex physiological fluid loaded with free 
oligosaccharides, glycoproteins, gangliosides, phagocytes, antimicrobial and immune-enhancing components which are unique compared to normal milk $[5,6]$. The core of the milk fat globule (MFG) is mainly composed of triacylglycerols (TAG); esters of fatty acids and glycerol constitute total $98 \%$ of milk lipids. MFGs originate near the basal region of the alveolar lumen of secretory cells as small droplets of fat. They migrate through the cytoplasm, gradually increasing in size, as the synthesis of TAG proceeds. MFG are secreted from the apical surface of the cell, surrounded by a thin biological bilayer membrane called the Milk Fat Globule Membrane (MFGM) [7, 8]. The MFGM contains many bioactive compounds which are involved with several biological functions and health benefits, such as neonatal gut maturation, antibacterial infection, inhibition of colon development and lowering cholesterol absorption [9, 10]. MFGM has an emulsifying and stabilizing effect in milk and prevents the aggregation and enzymatic degradation of the MFG $[9,11]$. These studies advanced the understanding of mammary function and milk secretion. Recently, articles on bovine mammary proteomics have been published, conducting a survey of proteins expressed in MFGM, and showing developmental changes during lactation phases [12, 13]. Considering the nutraceutical and biological significance of these proteins, currently there is an increased interest in MFGM [14]. Despite MFGM proteins making up only $1-4 \%$ of the total milk protein content, it is a protein family that shows a greater complexity than other fractions in milk $[15,16]$. The significance of MFGM proteins has been surveyed and examined by researchers, especially their bioactivities [17, 18]. Because of the functional and nutritional features of MFGM proteins, many components in mammalian milk have been examined [19, 20]. The different bioactive compounds on the MFGM are still being researched, but there are a variety of beneficial compounds such as lactoferrin, IgG, secretary $\operatorname{IgA}$, sialic acid, phospholipids, and gangliosides. Several of these constitutents are the key in antiviral and antimicrobial mechanisms that counter infections in the gut. Beneficial properties have been reported for even the membrane encasing the milk-fat. Adipophilin (milk synthesis), butyrophilin (multiple sclerosis suppression), cluster of differentiation (glycoprotein receptors), fatty acid binding protein (FABP; cell growth-inhibitor, anti-cancer factor, as selenium carrier), lactadherin (epithelialization, cell polarization, cell movement and rearrangement, synaptic activity, antiviral activity in gut), mucin (strong antiviral properties), xanthine oxidase/reductase (bactericidal agent) are the major FGM proteins [21]. Vitamin E and carotenoids, constituents of FGM, are antioxidative in nature [22]. Antioxidants can function by a number of mechanisms. Different enzymes can prevent the formation of radicals or scavenge radicals or hydrogen peroxide and other peroxides. Other enzymes catalyse the synthesis or regeneration of non-enzymatic antioxidants. In milk, antioxidant enzymes- superoxide dismutase and catalase have also been found. The FABP shows immunostimulating, opioid and antioxidant peptides. Because of MFGM's phospholipid enrichment and unique biochemical nature, we hypothesized that diets which include MFGM as a fat source might offer better protection against an exaggerated inflammatory response [23, 24, 25]. Compared to MFGM very little literature is available on colostrum fat globule membranes (CFGM). The limited work carried out so far on CFGM, from human and bovine sources, has focussed on the structural and developmental proteomes [26, 27, 28]. In the present study the FGMs were isolated from buffalo milk and colostrum. The antioxidant and reducing power assays were performed using different concentrations of milk and colostrum FGMs. CFGM sample exhibited higher antioxidant and reducing power than the MFGM extract.

\section{MATERIALS AND METHODS}

Colostrum and milk samples were collected from local healthy buffaloes (Bubalus bubilis) after parturition and stored at $20{ }^{0} \mathrm{C}$. Creams from both the samples were obtained by centrifugation at $4000 \mathrm{rpm}$ for $15 \mathrm{~min}$ at $4{ }^{\circ} \mathrm{C}$.

\subsection{Isolation of colostrum and milk fat globule membranes}

The FGM was extracted from cream as described by Basch et al. [29]. The cream was washed twice separately with phosphate buffer saline (PBS) $\left(0.01 \mathrm{M} \mathrm{Na} \mathrm{HPO}_{4} / \mathrm{NaH}_{2} \mathrm{PO}_{4} ; 0.9 \%\right.$ $\mathrm{NaCl}$; pH 7.2) (4500 xg, $10 \mathrm{~min}, 4{ }^{\circ} \mathrm{C}$ ) followed by water wash, once using double distilled water. Washed fat globules of both the samples were suspended in distilled water $(1: 1(\mathrm{v} / \mathrm{v}))$ and allowed to crystallize for $20 \mathrm{~h}$ at $4{ }^{\circ} \mathrm{C}$. Globules of both the samples were churned at $4{ }^{0} \mathrm{C}$ in a blender to separate the fat and serum fractions. Both the milk and colostum sample fractions were warmed at 45 ${ }^{0} \mathrm{C}$ for $30 \mathrm{~min}$, in order to melt the fat. The fat fractions were washed with distilled water for recovery of the residual serum. The total serum was centrifuged twice $\left(5000 \mathrm{xg}, 15 \mathrm{~min}, 4{ }^{0} \mathrm{C}\right)$ to remove traces of fat. We performed $\mathrm{MFG}$ protein delipidation with 4 volumes of ice cold acetone at $4{ }^{0} \mathrm{C}$ for $20 \mathrm{~min}$ at $8000 \mathrm{xg}$.

\subsection{Protein estimation}

Quantitative protein estimation of MFGM and CFGM samples was performed as described by Lowry et al. [30] using BSA as standard. To $1 \mathrm{ml}$ sample, $5 \mathrm{ml}$ of solution $\mathrm{C}$ [(Solution ' $A$ ' $50 \mathrm{ml}\left(2 \% \mathrm{NaCO}_{3}\right.$ in $\left.0.1 \mathrm{NaOH}\right)+1 \mathrm{ml}$ of reagent 'B' $(50 \mathrm{mg}$ $\mathrm{CuSO}_{4}$ dissolved in $\mathrm{H}_{2} \mathrm{O}$ containing $100 \mathrm{mg}$ of potassium sodium tartarate)] was added and incubated at room temperature for 10 min. Folin-Ciocalteu reagent $(0.5 \mathrm{ml})$ was added and mixed thoroughly. After incubation for $30 \mathrm{~min}$ at room temperature, colorimetric measurements were carried out at $660 \mathrm{~nm}$.

\subsection{SDS-PAGE analysis}

Fifty micrograms of the CFGM and MFGM proteins were separated by SDS-PAGE following the method of Webber and Osborn [31] in a 1-mm thick, $12 \%$ separating polyacrylamide gel under reducing conditions. The medium range standard protein ladder was obtained from Genei, Bangalore were used. Coomassie blue-R 250 staining was carried out to visualize the protein banding pattern. 


\subsection{DPPH (1,1-dipheny-2-picryl hydrazyl) radical scavenging assay}

DPPH radical scavenging assay was performed as described by Pulido et al. [32] with suitable modifications. To CFGM and MFGM samples (aliquots of 25, 50, 75 and $100 \mu \mathrm{g}$ in $50 \mu \mathrm{L}$ methanol) $1 \mathrm{ml}$ of $0.1 \mathrm{mM}$ DPPH in methanol and $450 \mu \mathrm{l}$ of $50 \mathrm{mM}$ Tris- $\mathrm{HCl}$ buffer ( $\mathrm{pH} 7.4$ ) were added. The scavenging of the DPPH radical was determined with respect to a control containing no scavenger. The reaction mixture was incubated at 37 ${ }^{0} \mathrm{C}$ for $30 \mathrm{~min}$, under dark conditions and spectrophotometric measurements were performed at $517 \mathrm{~nm}$. Ascorbic acid (10-100 $\mu \mathrm{g}$ ) was used as a positive control. The DPPH scavenging value was calculated by plotting the percentage of DPPH scavenging as a function of the concentration.

Percent inhibition $=[$ Control absorbance - Test absorbance/ Control absorbance] x 100

\subsection{Reducing power assay}

The method of Shinde et al. [33] was used with modifications. MFGM and CFGM at various concentrations (25, 50,75 and $100 \mu \mathrm{g}$ ) in $2.5 \mathrm{ml}$ distilled water was mixed with equal volumes each of sodium phosphate buffer $(0.2 \mathrm{M}, \mathrm{pH}$ 6.6) and potassium ferricyanide $(1 \%(\mathrm{w} / \mathrm{v})$ in water) in a test tube and incubated for $20 \mathrm{~min}$ at $50{ }^{\circ} \mathrm{C}$. The mixture was cooled using crushed ice and $0.5 \mathrm{ml}$ of trichloroacetic acid $(10 \%(\mathrm{v} / \mathrm{v})$ in water) was added and the total reaction mixture was centrifuged for 10 min, $3000 \mathrm{rpm}$, room temperature. One $\mathrm{ml}$ of the supernatant was collected and an equal volume of water was added with $0.2 \mathrm{ml}$ of $0.1 \%$ ferric chloride. The absorbance was read at $700 \mathrm{~nm}$ against the blank. Tannic acid was used as the standard. Increased absorbance reading indicates increased reducing power.

\subsection{Statistical analysis}

Data were analyzed by ANOVA followed by Tukey's multiple range test using the Statistical Analysis System Software. Significant differences were set at a $5 \%$ level $(\mathrm{p}<0.05)$.

\section{RESULTS}

Approximately $100 \mathrm{ml}$ of cream for a litre of milk and $230 \mathrm{ml}$ of cream for a litre of colostrums was recovered. FGMs were isolated from the creamy layer of both buffalo milk and colostrum. Depending on their lower buoyant density, FGMs fractionated on top during centrifugation and it was thoroughly washed to remove contaminating casein and whey proteins. Further, in order to prevent the interference of lipids during FGM protein analysis, samples were delipidized using ice cold acetone. The recovery of acetone washed dry FGMs were 2 and $8.4 \mathrm{gL}^{-1}$ respectively in milk and colostrum, the protein content was estimated to be $500 \mu \mathrm{g}$ and $700 \mu \mathrm{g}$ per mg dry weight of MFGM and CFGM respectively. The proteins in the washed cream were separated by SDS-PAGE (Figure 1). The molecular mass of major bands on the gel was estimated in comparison with the mobility of molecular weight standards. Based on the nomenclature recommended by Mather [21] the following major polypeptide bands corresponding to mucin $1(\mathrm{Mr}, 194 \mathrm{kDa})$, xanthine oxidase (Mr, $145 \mathrm{kDa})$, PAS III (Mr, 94kDa), PAS IV (Mr, $78 \mathrm{kDa})$, butyrophilin (Mr, 67kDa), PAS 6 (Mr, $50 \mathrm{kDa})$, PAS 7 (Mr, 47 $\mathrm{kDa})$ and FABP $(\mathrm{Mr}, 15 \mathrm{kDa})$ were identified with other minor proteins.

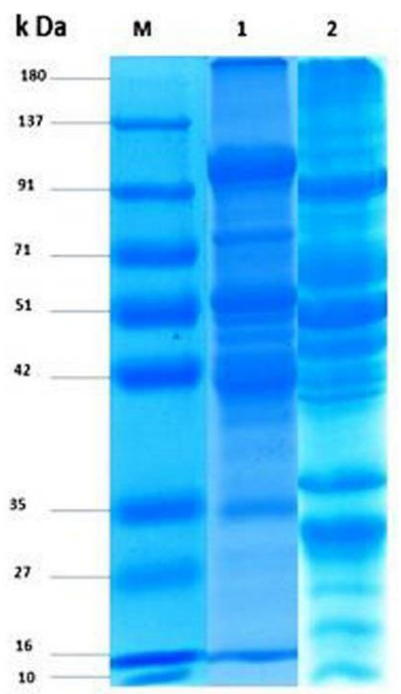

Fig. 1: SDS-PAGE analysis of MFGM and CFGM proteins. Fifty micrograms of the CFGM and MFGM proteins were separated by SDS-PAGE following the method of Webber and Osborn [31] in a 1-mm thick, $12 \%$ separating polyacrylamide gel under reducing conditions. Lane M- Standard protein molecular weight markers of medium range (10-180 kDa), lane 1- MFGM proteins, lane 2-CFGM proteins

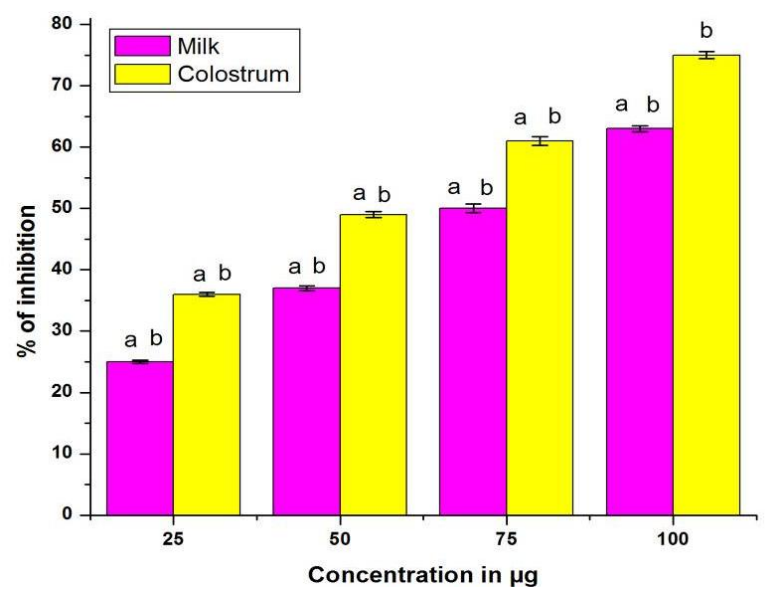

Fig. 2: DPPH assay showing percent inhibition for various concentrations of MFGM and CFGM fractions. Bars indicate \pm SE. Means designated with the same letter are not significantly different according to Tukey's multiple range test at $\mathrm{P}<0.05$.

The FGM fractions from both colostrums and milk were assayed for their antioxidant potential using free radical scavenging and reducing power assays. The free radical scavenging assay of samples were measured, showing reduction of DPPH radicals, can be observed by the decrease in absorbance at $516 \mathrm{~nm}$. Figure 2 shows that both CFGM and MFGM extracts displayed antioxidant activities with CFGM displaying $>10 \%$ 
higher free radical scavenging activity than MFGM at all the concentrations studied. Similarly, the CFGM sample exhibited over $>10 \%$ higher reducing power than MFGM at every concentration tested (Figure 3).

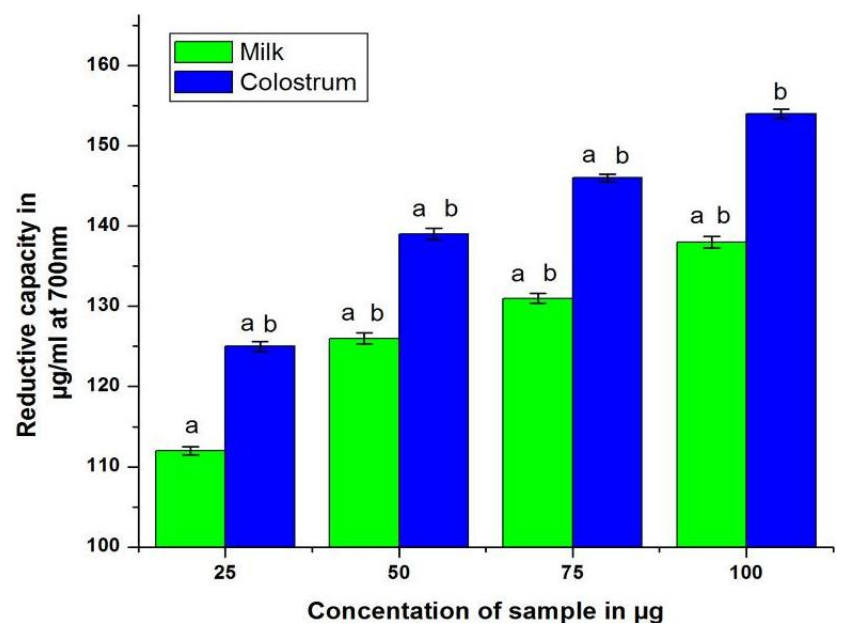

Fig. 3: Reducing capacity for various concentrations of MFGM and CFGM fractions. Bars indicate \pm SE. Means designated with the same letter are not significantly different according to Tukey's multiple range test at $\mathrm{P}<0.05$.

\section{DISCUSSION}

FGM is a complex biopolymer containing various beneficial proteins and lipids. The results of this study also support the hypothesis that dietary FGM proteins offers protection against oxidative stress [35, 36]. FGMs are distributed between intracellular, extracellular and membrane-associated proteins, and they are mainly involved in cell communication and signal transduction, immune function, metabolism, and energy production. Therefore, the consumption of dairy products enriched with MFGM could modulate the pathogenic response [16].

The fat content of colostrum was almost 2-fold higher than the milk and the protein content was also comparatively higher in CFGM. The CFGM exhibited higher scavenging and reductive capacity when compare to MFGM. In the gel, protein bands ranging in molecular weight from 47 to $200 \mathrm{kDa}$ were found to be major FGM proteins and remaining are casein and whey protein except FABP (Mr, $15 \mathrm{kDa}$ ) according to Mather [21].

DPPH assay was employed due to its high sensitivity when compared to other available assays like ABTS $\left(2,2^{\prime}\right.$-azinobis-3-ethylbenzthiazoline-6-sulphonic acid). In DPPH assay, the highest scavenging value of $75 \%$ was found for CFGM at $100 \mu \mathrm{g}$ and was found to be consistently higher than MFGM, at all the concentrations studied.

Reducing power assay is a popular method used in the assay of the antioxidant activities of various food derived samples and it employs the reduction of $\mathrm{Fe}^{3+}$ to $\mathrm{Fe}^{2+}$. The compound's reducing properties are generally associated with the presence of reductones [34], which have an antioxidant action by breaking the free radical chain by donating a proton. $\mathrm{Fe}^{2+}$ has been shown to produce oxyradicals and lipid peroxidation. This is because antioxidants are strong reducing agents. The highest reductive capacity obtained was $154 \mu \mathrm{g} \mathrm{ml}^{-1}$ for CFGM at the highest test concentration of $100 \mu \mathrm{g}$. The CMFG was found to be a better reducing agent than the MFMG, consistent with the DPPH scavenging activity assay.

Milk, a rich source of bioactive compounds can be used in the functional food production. Present day consumers are in the lookout for foods which offer protection against the lifestyle diseases in addition to their basic nutritional value. An in depth knowledge functional properties of milk compounds is a prerequisite in the design of such foods. Further development of economically viable industrial processes in the production of bioactive milk components is critical challenge to the food technologists $[21,23,24]$. The results obtained in the present study showcases the superior beneficial health effects of the CFGM over the MFGM.

\section{CONCLUSION}

The present study focused on antioxidant activity of FGM proteins from buffalo colostrum and milk. The study confirms the higher potential of CFGM proteins for free radical scavenging, compared to MFGM proteins. It provides useful information for increasing the commercial value of FGM proteins as an antioxidant. Further analysis of the FGMs will be carried out for its multifunctional properties.

\section{ACKNOWLEDGEMENTS}

We acknowledge the recognition of University of Mysore as an Institution of Excellence by the Government of India under MHRD-UGC programme for providing the infrastructure to perform the experiments.

Financial support and sponsorship: University Grants commission (UGC), New Delhi, India.

Conflict of Interests: There are no conflicts of interest.

\section{REFERENCES}

1. FAOSTAT. Production quantity of livestock primary 2012. Food and Agriculture Organisation of the United Nations - Statistics Division (Retrieved 23/10/2014 from http://faostat3.fao.org/download/Q/QL/E). 2012.

2. Ménard O, Ahmad S, Rousseau F, Briard-bion V, Gaucheron F, Lopez,C. Buffalo vs cow milk fat globules: Size distribution, zetapotential, compositions in total fatty acids and in polar lipids from the milk fat globule membrane. Food Chemistry. 2010; 120(2):544551.

3. Solah VA, Staines V, Honda S, Limley H. A Measurement of Milk Color and Composition: Effect of Dietary Intervention on Western Australian Holstein-Friesian Cow's Milk Quality. Journal of Food Science. 2007; 72(8):S560-S566.

4. Varricchio ML, Di-Francia A, Masucci F, Romano R, Proto V. Fatty acid composition of Mediterranean buffalo milk fat Fatty acid composition of Mediterranean buffalo milk fat, Italian Journal of Animal Science. 2007; 6:509-511.

5. Gopal PK, Gill HS. Oligosaccharides and glycoconjugates in bovine milk and colostrum. Brazilian Journal of Nutrition. 2000; 84:69-74. 
6. Aurelia P, Cristian C, Camelia R, Vioara M, Gheorghe M. The study of the main parameters quality of buffalo milk. African Journal of Microbiology. 2009; 10:201-206.

7. Wu CC. Proteomics reveal a link between the endoplasmic reticulum and lipid secretory mechanisms in mammary epithelial cells. Electrophoresis. 2000; 21:3470-3482.

8. Lopez C, Briad-Bion V, Menard O, Russeau F, Pradel P, Besle JM. Phospholipid, sphingolipid, and fatty acid compositions of the milk fat globule membrane are modified by diet. Journal of Agricultural and Food Chemistry. 2008; 56:5226-5236.

9. Dewettinck K, Rombaut R, Thienpont N, Le T T, Messens K and Camp JV. International Dairy Journal. 2008; 18:436-457.

10. Lopez C. Milk fat globules enveloped by their biological membrane: Unique colloidal assemblies with a specific composition and structure. Current Opinion in Colloid and Interface Science. 2011; 16:391-404.

11. Singh $\mathrm{H}$. The milk fat globule membrane-A biophysical system for food applications. Current Opinion in Colloid and Interface Science. 2006; 11:154-163.

12. Mather IH, Keenan TW. Origin and secretion of milk lipids. Journal of Mammary Gland Biology and Neoplasia 1998; 3:259-273.

13. Reinhardt TA, Lippolis JD. Bovine milk fat globule membrane proteome. Journal of Dairy Research. 2006; 73:406-416.

14. Fong BY, Norris CS. Quantification of milk fat globule membrane proteins using selected reaction monitoring mass spectrometry Journal of Agricultural and Food Chemistry. 2009; 57: 6021-6028.

15. Cavaletto M, Giuffrida M G and Conti A. Milk Fat Globule Membrane Components--A Proteomic Approach. Advances in Experimental Medicine and Biology. 2008; 606:129-141.

16. Riccio P. The proteins of the milk fat globule membrane in the balance. Trends in Food Science and Technology. 2004; 15(9): 458461.

17. Affolter M, Grass L, Vanrobaeys F, Casado B, Kussmann M. J. Qualitative and quantitative profiling of the bovine milk fat globule membrane proteome. Proteomics. 2010; 73:1079-1088.

18. Hettinga K, Van VH, De VS, Boeren S, Van HT, Van AJ and Vervoort J. The host defense proteome of human and bovine milk. PLoS One. 2011; 6, 1710-1712.

19. Kvistgaard AS, Pallesen LT, Arias CF, López S, Petersen TE, Heegaard CW and Rasmussen JT. Inhibitory effects of human and bovine milk constituents on rotavirus infections. Journal of Dairy Science. 2004; 8:4088-4096.

20. Spitsberg, VL. Bovine milk fat globule membrane as a potential nutraceutical. Journal of Dairy Science. 2005; 88(7):2289-2294.

21. Mather IH. A review and proposed nomenclature for major proteins of the milk-fat globule membrane. Journal of Dairy Science. 2000; 83:203-247.

22. Lindmark-Mansson H, Akesson B. Antioxidative factors in milk. British Journal of Nutrition. 2000; 84:S103-S110.

23. Dalbeth N, Gracey E, Pool B, Callon K, McQueen FM, Cornish J, MacGibbon A, Palmano K. Identification of dairy fractions with antiinflammatory properties in models of acute gout. Annals of the Rheumatic Diseases. 2010; 69:766-769.

24. Park E J, Thomson AB, Clandinin R MT. Protection of intestinal occludin tight junction protein by dietary gangliosides in lipopolysaccharide-induced acute inflammation. Journal of Pediatric Gastroenterology and Nutrition. 2010; 50:321-328.
25. Alwani ME, Wu BX, Obeid LM, Hannun YA. Bioactive sphingolipids in the modulation of the inflammatory response. Pharmacology and Therapeutics. 2006; 112:171-183.

26. Fortunato D, Giuffrida M. G, Cavaletto M, Garoffo L. P, Dellavalle G, Napolitano L, Giunta C, Fabris C, Bertino E, Coscia A. Structural proteome of human colostral fat globule. Proteomics . 2003; 897905.

27. Reinhardt T, Lippolis J. D. Developmental changes in the milk fat globule membrane proteome during the transition from colostrum to milk. Journal of Dairy Science. 2008; 91 (6), 2307-2318.

28. Yang M, Cong M, Peng X, Wu J, Wu R, Liu B, Yue X. Quantitative proteomic analysis of milk fat globule membrane (MFGM) proteins in human and bovine colostrum and mature milk samples through iTRAQ labeling. Food and function. 2016; 2438-2450.

29. Basch JJ, Greenberg R, Farrell HM. Identification of the milk fat globule membrane proteins.: II. Isolation of major proteins from electrophoretic gels and comparison of their amino acid compositions. Biochimica et Biophysica Acta (BBA)-Protein Structure and Molecular Enzymology, 1985; 830(2): 127-135.

30. Lowry $\mathrm{OH}$, Rosebrough NJ, Farr AL, Randall RJ. Protein measurement with the Folin phenol reagent. Journal of Biological Chemistry. 1951; 193:266-275.

31. Weber K, Osborn M. The reliability of molecular weight determinations by sodium dodecyl sulfate-polyacrylamide gel electrophoresis. Journal of Biological Chemistry. 1969; 244: 44064412.

32. Pulido R, Bravo L, Saura CF. Antioxidant activity of dietary polyphenols as determined by a modified ferric reducing/antioxidant power assay. Journal of Agricultural and Food Chemistry. 2000; (48):396-3402.

33. Shinde UA, Phadke AS, Nair AM, Mungantiwar AA, Dikshit VJ, Saraf MN. Membrane stabilizing activity - a possible mechanism of action for the anti-inflammatory activity of Cedrus deodara wood oil, Fitoterapia. 1999; 70:251-257.

34. Pawar N, Kogje A, Bhondave P, Nagarkar B, Kulkarni O, Harsulkar A, Jagtap S. Comparative free radical scavenging and antiinflammatory potential of branded market samples of an ayurvedic formulations: Dashamoolarishta. International Journal of Pharma and Bio Sciences. 2013; 4(1):789-799.

35. Jensen RG, Ferris AM, Lammi-Keefe CJ. The composition of milk fat. Journal of Dairy Science. 1991; 74:3228-3243.

36. Chen J, Lindmark-Mansson H, Gorton L, Åkesson B. Antioxidant capacity of bovine milk as assayed by spectrophotometric and amperometric methods. International Dairy Journal. 2003; 13:927-935.

\section{How to cite this article:}

Brijesha N, Aparna HS. Buffalo (Bubalus bubilis) colostrum and milk fat globule membrane fractions are potent antioxidants. J App Biol Biotech. 2017; 5 (02): 089-093. DOI: 10.7324/JABB.2017.50214 